\title{
WAREHOUSE AND TRANSPORT PROCESSES BASED ON THE EXAMPLE OF A SELECTED ENTERPRISE FROM THE ELECTRICAL INSTALLATION INDUSTRY
}

\begin{abstract}
This article presents the course of warehouse and transport processes on the example of a selected enterprise from the electrical installation industry. The warehouse infrastructure - finished goods warehouse, technical means of manipulation and storage devices were characterized. The analysis of the storage process was performed using a map of processes and indicators for warehouse management, for warehouse and technical performance indicators. The second part of the article deals with the analysis of the transport process. The enterprise's own transport was compared with the possibility of outsourcing this service. The transport process was also analyzed using the mapping and indicator methods. Thus, this article uses such methods as analysis, process mapping and indicators to diagnose the analyzed processes. The article also presents further research directions.
\end{abstract}

Keywords: warehouse and transport processes, process map, logistic indicators JEL: L91, M10, O10

\section{Introduction}

Both warehousing and transport are important processes in the distribution of products (Dyczkowska, 2014). The movement of products between specific links in the logistics chain always involves the need to hold these products in certain places and for a certain period of time. The organization of all activities related to this process is among the most important components of logistics as it significantly affects the efficiency of flows of goods. This is related to the number and type of operations in the order picking area, i.e. the warehouse capacity which 
is measured by the number of cargoes received and issued per year. The transport process is generally considered as a key factor in distribution (Bendkowski, Kramarz, 2011). This process which is carried out using means of transport is divided into the following phases: conceptual preparation of movement, preparation of cargo for transport, organization of the process of carriage, the physical movement of cargo, handling of the process in legal and financial terms and cost analysis and transport process evaluation.

Companies performing at least some of the transport-related operations using their own resources usually have a special dedicated unit (a separate department or an organizational unit) for this purpose. The resources of this unit make up the transport base. This base includes not only the means of transport and people responsible for their use, but also all resources for loading, unloading and handling of goods as well as equipment supporting documentation and information processes. The purpose of this article is to analyze the warehouse and transport processes of a selected enterprise from the electrical installation industry.

The warehouse infrastructure - a finished goods warehouse, the technical means of manipulation and storage devices are characterized. The analysis of the storage process was performed using a map of processes and indicators for warehouse management, for the warehouse and technical performance indicators. The second part of the article deals with the analysis of the transport process. The enterprise's own transport was compared with the possibility of outsourcing this service. The transport process was also analyzed using the mapping method as well as the index method (quantitative and qualitative indicators, e.g. transport costs per $\mathrm{km}$ or transport reliability). Thus, this article uses such methods as analysis, process mapping and indicators to diagnose the analyzed processes. The process mapping method allows the presentation of subsequent process activities at the assumed level of detail and identification of all resources supplied to the process. Logistic indicators help to control processes. The results of these indicators allow obtaining a picture of the company's condition and introducing changes that improve its functioning (Miłaszewicz, Wengel, 2015). Process indicators support the analysis as they help understand what is happening inside them (Dohn, 2006). As with streamlining and reorganizing processes, if we do not know where we are, we will not get where we want to be. Indicators specify the goals and responsibilities, facilitate focusing on key activities, and are the basis for reasonable judgments.

This article poses the following questions: What characterizes the process of storage and transport of products in the electrical installation industry? How does the analyzed entity implement these processes and how does it control them? Is it possible to improve these processes?

\section{Warehouse process description}

The warehouse process comprises all activities consisting in picking and packing of products for each order. Alternative solutions related to the delivery may be reflected in the course of specific activities and in the costs. As far as standard orders are concerned the time to fill an order in the analyzed company is from 
several up to 36 hours. The sales department issues an invoice and a goods issue document (a goods issue note) using a computer. Goods issue notes are grouped on the basis of transport routes and directions to reach recipients. The information is forwarded to the sales unit in the shipping department. Having received a goods issue note, the warehouse worker analyzes it in terms of the volume of ordered goods and whether pallets should be used or not. Not every shipment needs pallets. If batches are small, or when a customer handles the transport on his own and specifies in the order that pallets should not be used, the warehouse worker assembles goods on a warehouse trolley. However, in most cases orders are on pallets. The order picking activities include:

- picking up goods from the storage area and transporting to the loading area;

- depalletizing;

- palletizing shipping pallets and protection of pallets, i.e. wrapping in foil to prevent movement of goods.

Then, the complete order in the form of shipment is delivered to the loading ramp. When the goods are issued and loaded onto the means of transport it is checked if the actual quantity of goods is the same as the quantity stated in the goods issue documents. The carrier confirms receipt of the goods on the goods issue note. This document with a copy of the invoice are archived in a unit of the Finished Goods Warehouse. From the moment of loading to the moment goods are delivered to a customer the responsibility for the order fulfilment lies with the carrier.

\subsection{Warehouse infrastructure}

Operations related to the picking and issue of goods require that various technical measures are used to ensure that these operations are carried out effectively. These measures make up the infrastructure of warehouse processes. In the analyzed company which has high production volumes, this infrastructure is very complex and includes many components. These are in particular:

- the warehouse building;

- technical manipulation equipment;

- warehouse equipment.

\section{The finished products warehouse}

The enterprise has a finished products warehouse which is a steel building with the usable height $\mathrm{h}=700 \mathrm{~cm}$. The building comprises a one-storey warehouse section and a two-storey back section. The overall dimensions are the following:

- development area $-709.20 \mathrm{~m}^{2}$;

- usable area - $619.42 \mathrm{~m}^{2}$;

- cubic space $-5607.00 \mathrm{~m}^{3}$.

\section{Technical manipulation equipment}

The firm uses technical and transport equipment in the warehouse processes related to order picking. These include:

- a high lift truck - designed for storing and transporting (at short distances) all kinds of goods on pallets, in boxes, etc.; 
- pallet trucks - suitable for horizontal transport, at low heights, of cargoes placed on euro pallets, non-standard pallets, stands and in containers;

- hand pallet trucks with hydraulic lifting - necessary for loading and unloading operations;

- hand trolleys - where the trolley handrail can be folded which makes it easier to transport loads;

- a travelling ladder with extension of up to $4 \mathrm{~m}$.

\section{Warehouse equipment}

The main warehouse of the enterprise is equipped with APR 12 high storage racks which are used for storing inventory in the form of pallet unit loads. The maximum shelf capacity is 885 pallet spaces. Owing to the high storage racks it is possible to use the storage space in a highly effective way and store inventory at five storage levels:

- level one is used for storing products in smaller unit loads - unit or bulk packaging;

- levels: two, three, four and five are used for storing palletized products.

\subsection{Warehouse process analysis}

The warehouse process analysis was conducted on the basis of: the process mapping method and the indicator analysis.

The activities comprising the storage process are presented in the process map (Figure 1).

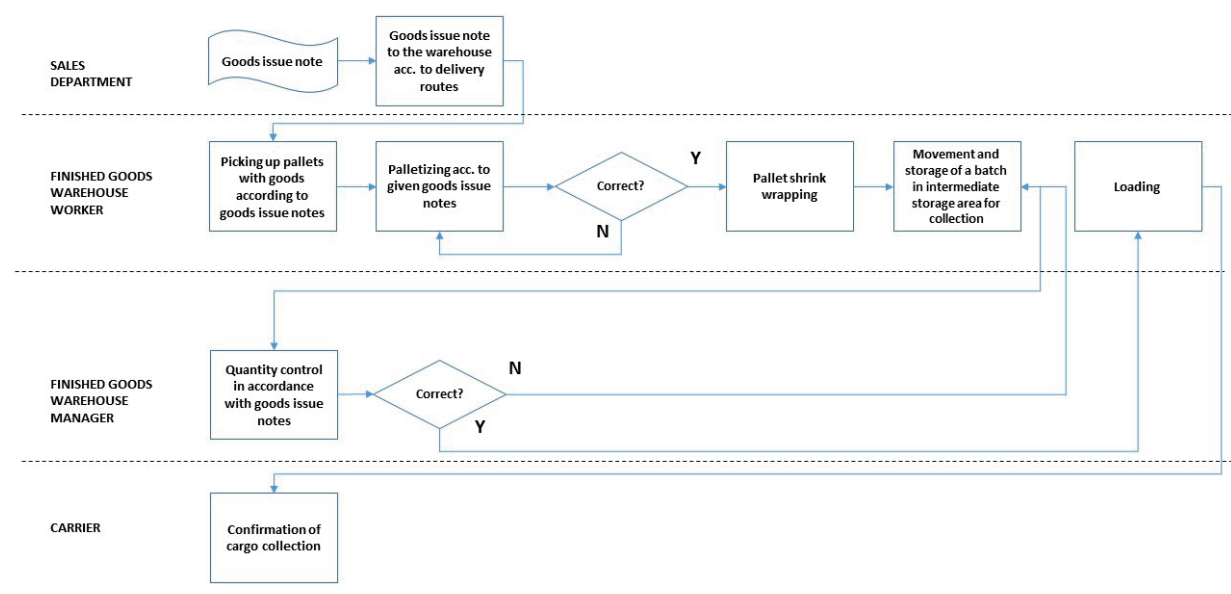

Figure 1. Warehousing process - process map

Source: (own elaboration based on information provided by the enterprise)

The warehouse process analysis shows a very significant problem related to determining the size of inventory. The software used by the company does not have the function of inventory and procurement management. Workers do 
not make any calculations concerning the optimal stock levels, nor do they set the safety stock or the optimum delivery batch. As the entire warehousing process is overseen by the marketing department staff, it is necessary to add additional modules to the software.

The indicator analysis of the warehousing process uses variables which are measured in the analyzed enterprise throughout the accounting period, as well as at certain selected points of time. The variables are used to construct indicators to evaluate the warehouse process. These figures are presented in Table 1.

Table 1. Warehouse process measures

\begin{tabular}{|l|l|}
\hline \multicolumn{1}{|c|}{ Warehouse process variables } & \multicolumn{1}{|c|}{ Measurement in time (year) } \\
\hline Value of inventory & PLN 9150156.12 \\
\hline Orders processed immediately & 15650 \\
\hline Orders processed within 48 hours & 13870 \\
\hline Warehouse area & $619.42 \mathrm{~m}^{2}$ \\
\hline Cubic space & $5607.00 \mathrm{~m}^{3}$ \\
\hline Storage capacity in unit loads & 885 pallet spaces \\
\hline
\end{tabular}

Source: (own elaboration based on information provided by the enterprise)

The following indicators were used to analyze the warehouse process (Twaróg, 2003): warehouse management indicators, warehouse indicators, technical performance indicators.

\section{Warehouse management indicators}

Meeting the demand projection:

$$
\frac{\text { actual demand }}{\text { projected demand }} \times 100 \%=\frac{3807666}{3400000} \times 100 \%=111.99 \%
$$

Indicator of orders accepted for processing to all orders incoming in the analyzed period:

$$
\frac{\text { accepted orders }}{\text { total orders }} \times 100=\frac{15630}{15650} \times 100 \%=99.87 \%
$$

Indicator of fulfilled orders to all accepted orders:

$$
\frac{\text { fulfilled orders }}{\text { accepted orders }} \times 100 \%=\frac{15630}{15630} \times 100 \%=100 \%
$$

\section{Warehouse indicators}

Warehouse use rate:

$$
\frac{\text { occupied pallet spaces }}{\text { total spaces }} \times 100 \%=\frac{880}{885} \times 100 \%=99.44 \%
$$

Usable area effectiveness:

$$
\frac{\text { usable area }}{\text { storage capacity in inventory units }} \times 100=\frac{619.42}{885} \times 100=0.72 \mathrm{~m}^{2} / \text { pallet }
$$


Warehouse usable cubic space effectiveness:

$\frac{\text { cubic space used }}{\text { storage capacity in inventory units }} \times 100=\frac{5607,00}{885} \times 100=6.33 \mathrm{~m}^{3} /$ pallet

\section{Technical performance indicators}

Indicator of storage space technical equipment:

$\frac{\text { value of warehouse technical equipment }}{\text { usable storage capacity }} \times 100=\frac{150000}{5607} \times 100=$ PLN 26.75/. $\mathrm{m}^{3}$

Indicator of means of transport for storage space:

$\frac{\text { value of warehouse means of transport }}{\text { warehouse usable cubic space effectiveness }} \times 100=\frac{120000}{5607} \times 100=$ PLN 21.40/m $\mathrm{m}^{3}$

The results in the category evaluating the warehouse management seem to be of particular importance in this case. Attention should be paid most of all to the high values of the following indicators:

- fulfilled orders - at the level of $100 \%$. This indicator shows that the operations related to the order picking are correct and with no errors. It is due to the checking system in place in the warehouse and the competence of employees;

- warehouse use rate $-99.44 \%$. This indicator shows to what extent the warehouse space is used for finished products.

On such basis the following conclusions can be drawn:

- the quantity of finished products in the warehouse is large. The enterprise intending to increase the capacity in the future, or to increase the inventory, will have to invest to enlarge the existing storage space or build a new warehouse;

- cash blocked in the inventory of finished products is of high value.

Table 2. Warehouse process measures - summary table

\begin{tabular}{|c|c|c|}
\hline Indicator & Indicator value & Standards \\
\hline \multicolumn{3}{|c|}{ Warehouse management indicators } \\
\hline Meeting the demand forecast & $111.99 \%$ & $90 \%$ \\
\hline Orders accepted to fill to total orders & $99.87 \%$ & $90 \%$ \\
\hline Orders filled to orders accepted & $100 \%$ & $95 \%$ \\
\hline \multicolumn{3}{|c|}{ Warehouse indicators } \\
\hline Warehouse use rate & $99.44 \%$ & $80 \%$ \\
\hline Usable area effectiveness & $0.70 \mathrm{~m}^{2} /$ pallet & - \\
\hline Warehouse usable cubic space effectiveness & $6.33 \mathrm{~m}^{2} /$ pallet & - \\
\hline \multicolumn{3}{|c|}{ Technical performance indicators } \\
\hline Storage space technical equipment & PLN $26.75 / \mathrm{m}^{3}$ & - \\
\hline Means of transport for storage space & PLN $21.40 / \mathrm{m}^{3}$ & - \\
\hline
\end{tabular}

Source: (own elaboration based on information provided by the enterprise) 


\section{Transport process description}

The analyzed enterprise delivers its products by using:

- its own vehicle fleet which includes vehicles of the following types:

- Volkswagen Transporter - 2 vehicles;

- Lublin - 2 vehicles;

- regular carriers with which the enterprise enters into contracts for transport services;

- customer transport.

A transport service to deliver a product to the customer is initiated by the Shipping Unit dispatcher on the basis of a "delivery order" received from the marketing department. The order having been received, the dispatcher records it in a special register. The register includes - similarly as in the case of registration of inquiries or orders - such basic information as:

- date on which a request for quotation is received;

- name of the customer;

- date and place of delivery.

Then, the dispatcher analyzes the order in terms of how it can be executed.

This activity includes:

- checking the delivery date set by the customer - usually orders are carried out in two ways:

- immediately - if received by 12.00 ;

- on the next day after receipt of the order - if received after 12.00;

- checking how large the order is in terms of quantity.

\subsection{Shipping}

Having analyzed the document, the dispatcher decides what means of transport to select. It should be noted at this point that the shipping department worker can only choose between the enterprise's own transport and transport companies. In situations where the customer decides to pick up the purchased products himself, the marketing department worker bypasses the shipping department and transfers the order directly to the sales department.

\section{Transport companies}

At the present time, the enterprise uses the services of DHL Express under a commercial contract. The procedure to select the appropriate carrier that could take over some of the enterprise's transport services was very careful. When making decisions to select the transport operator, the enterprise is guided by the following criteria:

- required knowledge and technical experience;

- ensured continuity of deliveries;

- financial problems;

- liability for losses;

- reputation of the supplier;

- price; 
- quality and method of quality control;

- time of performance;

- storage problems;

- legal issues.

The management expected that the logistics operator would most of all help achieve such goals as reduction of logistics costs and improving the enterprise's competitive position. In the course of negotiations, a commercial contract was executed between the enterprise and the logistics operator, DHL Express.

The carrier's tasks stipulated in the contract include:

- carriage of goods;

- protection of cargo against damage in transit;

- loading and unloading of goods;

- the carrier's liability for the consigned cargo.

\section{Own transport}

As the number of delivery vans is small the share of the enterprise's own transport is at the level of $35 \%$ and $65 \%$ is outsourced using specialized transport companies. The dispatcher decides to use the enterprise's own transport when:

- the processed order will ensure a full load of the vehicle in terms of quantity and volume;

- the place of delivery is within a distance of approx. $100 \mathrm{~km}$ from the enterprise's site;

- several smaller orders are addressed to the same destination or a close place at the same time.

The dispatcher's work affects the efficiency of the whole physical distribution process. The accurate organization of vehicle routes guarantees that:

- the distribution costs are minimized;

- orders are executed on a 48-hour basis;

- less equipment and fewer people are needed to execute all orders;

- the customer satisfaction level is higher owing to the rapid processing of an order.

\subsection{Delivery}

Where the enterprise's own transport is chosen, the dispatcher requests the appropriate vehicle and issues a transport order document. Such order is confirmed by the driver's signature. However, if the dispatcher decides to commission a carrier to perform the service, he/she confirms the order himself/herself, at the same time requiring a warehouse worker should confirm a waybill which is the basis for settlement of the work of DHL Express drivers. Based on the documents received from the dispatcher, the driver collects the products and executes the transport order. When the order is carried out by the logistics operator, the responsibility for the quality of the product in transit rests with the carrier.

\section{Transport process analysis}

Similarly to the storage process, the transport process analysis was conducted on the basis of the process mapping method and the indicator analysis. The activities comprising the transport process are presented in the process map (Figure 2). 
The transport process analysis using the mapping method showed issues related to providing the dispatcher with information about the actual delivery volume. This issue had already been outlined earlier with the analysis of the customer service process. The dispatcher's task could be facilitated, if a tool that is used by logistics operators, the so-called price calculator were developed. While making a decision to use the services of a private carrier, the dispatcher could calculate the cost of the service offered by the operator in a short time.

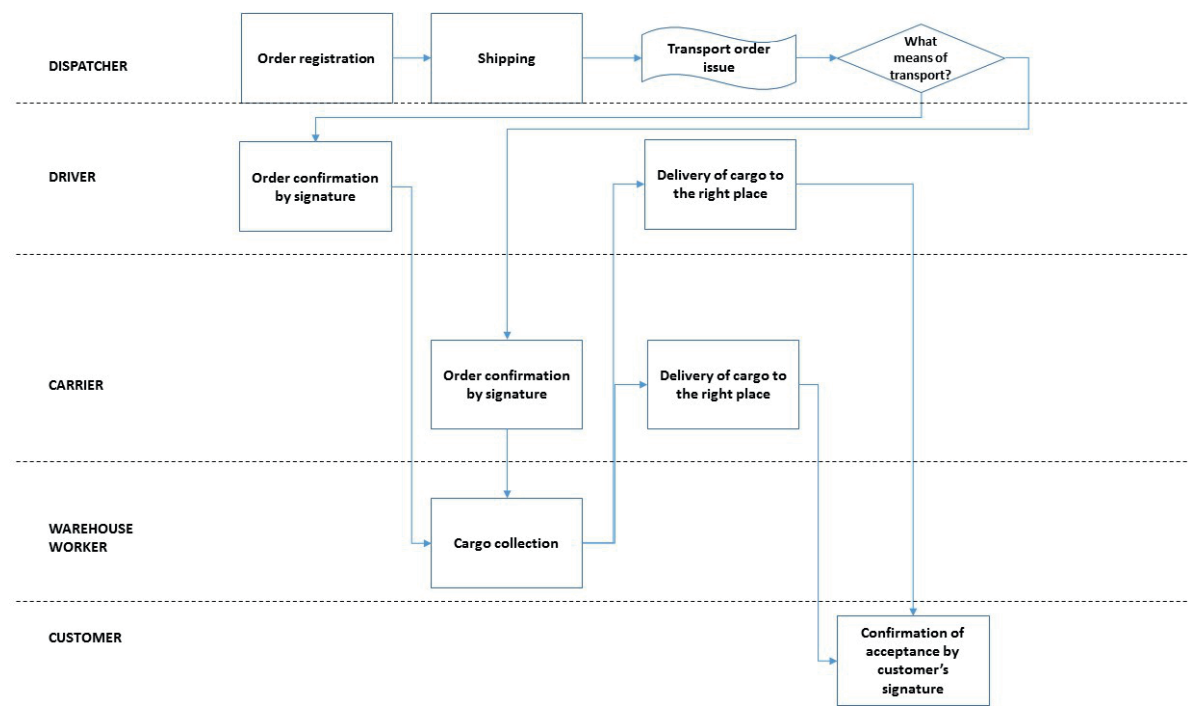

Figure 2. Transport process map

Source: (own elaboration based on information provided by the enterprise)

\section{Transport process indicator analysis}

The indicator analysis of the transport process uses variables shown in Table 3. The variables include figures that are measured throughout the accounting period as well as at selected points of time. Most variables are recorded and settled in the enterprise's Controlling Department.

Table 3. Transport process measures

\begin{tabular}{|l|l|}
\hline \multicolumn{1}{|c|}{ Transport process variables } & \multicolumn{1}{c|}{ Measurement in time (year) } \\
\hline The number of kilometres travelled & $35053.0 \mathrm{~km}$ \\
\hline Number of transport workers, including: & 7 \\
- day pay workers - drivers & 6 \\
- white-collar workers & 1 \\
\hline Nominal working time & $11520 \mathrm{~h}$ \\
\hline Used working time & $5007.63 \mathrm{~h}$ \\
\hline Transport costs & PLN 266405.80 \\
\hline Number of shipments & 15630 \\
\hline
\end{tabular}

Source: (own elaboration based on information provided by the enterprise) 
The following indicators are used in the transport process analysis (Twaróg, 2003): quantitative indicators, qualitative indicators.

Quantitative indicators - transport cost per kilometre:

$$
\frac{\text { cost of transport }}{\text { kilometres }} \times 100=\frac{266405.80}{350534.00} \times 100=0.76 \mathrm{zl} / \mathrm{km}
$$

Quantitative indicators - transport cost per shipment:

$$
\frac{\text { cost of transport }}{\text { cost of shipments }} \times 100=\frac{266405.80}{15630} \times 100=\text { PLN 17.05/pcs }
$$

Quantitative indicators - use of working time:

$$
\frac{\text { use of working time }}{\text { nominal working time }} \times 100=\frac{5007.63}{11520} \times 100=43.47 \%
$$

Qualitative indicators - transport reliability:

$$
\frac{\text { transport tasks completed on time }}{\text { total transport tasks }} \times 100=\frac{15310}{15630} \times 100=97.95 \%
$$

\begin{tabular}{|c|c|c|}
\hline Indicator & Indicator value & Standards \\
\hline \multicolumn{3}{|c|}{ Quantitative indicators } \\
\hline Transport cost per kilometre & PLN $0.76 \mathrm{zl} / \mathrm{km}$ & 0.71 \\
\hline Transport cost per shipment & PLN 17.05/shipment & - \\
\hline Use of working time & $43.47 \%$ & $100 \%$ \\
\hline \multicolumn{3}{|c|}{ Qualitative indicators } \\
\hline Transport reliability & $99.44 \%$ & $99 \%$ \\
\hline Transport flexibility & $0.70 \mathrm{~m}^{2} /$ pallet & - \\
\hline
\end{tabular}

Qualitative indicators - transport flexibility:

$$
\frac{\text { transport requirements fulfilled }}{\text { total requirements }} \times 100=\frac{1680}{1720} \times 100=97.67 \%
$$

Table 4. Transport process measures - summary table

Source: (own elaboration based on information provided by the enterprise)

The results obtained when performing the indicator analysis reflect a good appraisal of the company in terms of accomplishing transport tasks related to the transport of finished products to the customer. Most of the orders are processed on the same day and the remaining ones within the contractual 48 hours. The indicator concerning the information on the use of working time may become a starting point for analysis of a possible reduction of the number of employees in the transport department. However, the low value of this indicator results from the nature of the work of drivers who are instructed to take on other tasks when there are no transport orders. The indicators concerning reliability and flexibility, which are at the level of $98 \%$, demonstrate the high quality of the transport processes conducted by the analyzed company.

The use of the process mapping method and indicators made it possible to draw conclusions as to the effectiveness of logistics activities carried out in the company. By answering the questions asked, it can be stated that these processes are implemented 
smoothly in the company. It could be done for the analyzed processes, e.g. value stream maps, in order to find possible sources of waste in these processes. Separate processes responsible for the physical distribution of finished products and their assessment in terms of the criteria: time, quality and cost can become an area of further research. Namely, it can be examined how distribution logistics processes (transport and storage) affect the profitability of an enterprise. Distribution processes include at least several types of activities (order processing, storage, handling and transport). Each of these activities is very important for the company's financial standing. Often, the quality of logistics processes determines which market segment manages to master a given company, effectively displacing competitors. Similarly, the efficiency of logistics processes, especially in the sphere of distribution, can be a direct factor in increasing revenues from the sale of products, goods and services. Logistics processes are therefore closely related to the volume of revenues obtained from the company's activities, as well as the costs that are incurred in this respect.

\section{Conclusions}

Distribution processes consist in at least several types of activities, including processing of orders, storage, handling, manipulation and transport. Each of these activities is very important for the financial situation of an enterprise. The quality of logistics processes often determines which market segment can be won by a given company effectively driving competitors out. Similarly, the efficiency of logistics processes, particularly in the area of distribution, may be a direct factor in increasing revenues from sale of products, goods and services. Generating revenues and costs of the enterprise logistics processes directly affect profitability of the business. All the advantages of the organization can be efficiently and effectively used when logistics processes are realistically embedded in the operations of the enterprise. Hence, if the process is to be formed correctly, it would require first of all to take into account the opportunities arising from the organization of work, the knowledge and skills of contractors, as well as proper selection of contractors for the anticipated tasks and the careful observation of the environment in which the process is to be implemented.

\section{References}

Bendkowski, J., Kramarz, M. (2011), Logistyka stosowana - metody, techniki, analizy - części I i II, Wydawnictwo Politechniki Śląskiej, Gliwice.

Dohn, K. (2006), Studium oceny procesu produkcyjnego w przedsiębiorstwie przemysłowym, Wydawnictwo Politechniki Śląskiej, Gliwice.

Dyczkowska, J. (2014), Projektowanie procesów logistycznych w przedsiębiorstwach produkcyjnych - przesłanki. Logistyka, 4.

Miłaszewicz, B., Wengel, M. (2015), Wskaźnikowa ocena funkcjonowania logistyki dystrybucji. Logistyka, 6 .

Twaróg, J. (2003), Mierniki i wskaźniki logistyczne, Instytut Logistyki i Magazynowania, Poznań.

\section{Corresponding author}

Jadwiga Grabowska can be contacted at: jadwiga.grabowska@polsl.pl 